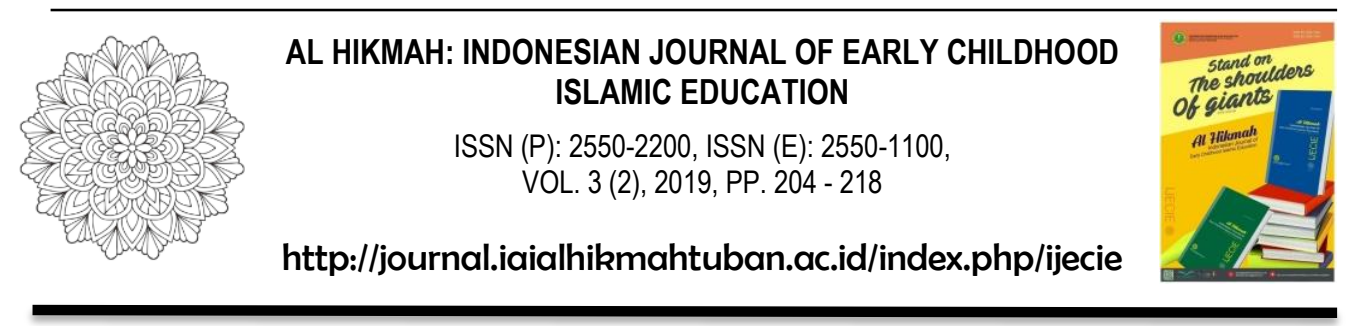

\title{
PEMBELAJARAN SAINTIFIK MELALUI METODE BERCERITA UNTUK PERKEMBANGAN KOGNITIF ANAK RA KELOMPOK A MAMBAUL ULUM
}

\author{
Siti Fatimah \\ Prodi Manajemen Pendidikan Islam, STAI Al Hikmah Tuban \\ sitifatimah1411@gmail.com
}

\begin{abstract}
Abstrak
Penelitian ini bertujuan untuk mendeskripsikan implementasi pembelajaran saintifik melalui metode bercerita, metode/teknik bercerita untuk pengembangan kognitif, serta faktor pendukung dan penghambat dari pelaksanaan pembelajaran Saintifik dengan metode bercerita. Metode yang digunakan dalam penelitian ini melalui wawancara dan observasi serta dokumentasi. Hasil penelitian menunjukkan 1) Pendekatan saintifik di RA kelompok A Mambaul Ulum sudah baik dan dilaksanakan sesuai dengan prosedur dan melibatkan semua panca indera seperti mengamati, menanya, mengumpulkan informasi, mengolah informasi dan mengomunikasikan 2) Metode yang dipakai oleh guru RA kelompok A Mambaul Ulum dengan memberikan cerita sesuai dengan tema dan selalu menggunakan media serta menggunakan cara yang menarik agar anak mampu memusatkan perhatianya pada cerita guru 3) Faktor pendukung yaitu program kepala RA kelompok A terkait peningkatan kapasitas guru dalam bercerita yang rutin dilaksanakan oleh IGRA Kecamatan. Faktor penghambat, tidak semua orang tua siswa mampu melakukan follou Up dan menjadi contoh dalam mendukung pengembangan kognitif anak ketika berada dirumah.
\end{abstract}

Kata Kunci: Pembelajaran Saintifik, Metode Bercerita, Pengembangan Kognitif

\section{Abstract}

This research aims to describe implementation of scientific learning through storytelling methods, methods/techniques of storytelling for cognitive development, supporting and inhibiting factors of implementing Scientific learning with the storytelling method. The method used in this research through interviews and observation and documentation. The results showed 1) The scientific approach in group A of RA Mambaul Ulum was good and was carried out in accordance with procedures and involved all five senses such as observing, asking questions, gathering information, processing information and communicating 2) The method used by teachers of group A of RA Mambaul 
Ulum by giving stories in accordance with the theme and always using the media and using interesting ways so that children are able to focus their attention on the teacher's story 3) Supporting factors were the program of the headmaster of $R A$ related to increasing teacher capacity in storytelling which was routinely carried out by IGRA at the Sub-district. The inhibiting factors consisted of not all parents of students were able to do follow Up and became an example in supporting the cognitive development of children at home.

Keywords: Scientific Learning, Storytelling Method, Cognitive Development

\section{PENDAHULUAN}

Anak merupakan suatu amanah dari Allah dan harta yang paling berharga. Jika anak dibiasakan untuk melakukan kebaikan niscaya anak akan tumbuh menjadi baik. Anak merupakan aset negara, pada pundak mereka memikul tanggung jawab dan kelangsungan kehidupan negara dan bangsa. Jika sejak dini anak dibekali dengan pendidikan dan nilai-nilai yang baik maka kelak mereka akan mampu mengenali potensi-potensi yang ada pada dirinya sehingga mereka dapat menyumbangkan potensi tersebut untuk kemajuan bangsa dan negara agar mampu bersaing di era globaliasi (Suyadi, $2013: 6$ ).

Penelitian tentang otak menunjukkan bahwa apabila anak diberikan rangsangan sejak usia dini, maka akan ditemukan anak-anak yang mempunyai potensi unggul di dalam dirinya karena pada dasarnya setiap anak mempunyai kemampuan tak terbatas di dalam dirinya. Anak memerlukan program pendidikan yang mampu membuka dan merangsang kapasitas belajar dan pengembangan potensi diri anak melalui pembelajaran sedini mungkin, apabila potensi itu tidak dapat direalisasikan dan dikembangkan, maka sama artinya anak tersebut telah kehilangan periode emas dalam hidupnya (Sumiyati, 2014 :13-14)

Anak usia dini merupakan masa cemerlang untuk menumbuhkan potensi anak. Pembelajaran pada anak usia dini itu usia ini membutuhkan semangat tinggi untuk melakukan pembelajaran, pembelajaran di usia anak 
usia dini perlu dilakukan secara serius, karena masa ini kecerdasan semua organ tubuh terasah, ini merupakan tantangan bagi guru untuk mensukseskan pembelajaran anak usia dini yang akan melahirkan kecerdasan kognitif, afektif dan psikomotorik. Pelaksanaan pembelajaran pada prasekolah (TK/RA) Yang selama ini cenderung lebih bersifat "akademik" perlu dikembangkan ke arah pembelajaran sesuai dunianya, yaitu memberikan kesempatan kepada siswa untuk aktif dan kreatif, dengan menerapkan konsep belajar sambil bermain.

Pembelajaran saintifik merupakan keterampilan dalam proses pembelajaran yang menggunakan pendekatan saintifik, baik ketrampilan guru dalam mengajar disebut ketrampilan belajar saintifik guru (Scientifik learning skill guru) maupun anak dalam belajar disebut ketrampilan pembelajaran saintifik siswa (Scientific Learning Skill Siswa). Ketrampilan (Skill) diharapkan menghasilkan guru profesional yang memiliki highskill atau skillfull, maupun ketrampilan siswa dalam melaksanakan pembelajaran dengan pendekatan saintifik (Siti Johariyah, 2015).

Pembelajaran saintifik dimaksudkan untuk memberikan pemahaman kepada peserta didik dalam mengenal, memahami berbagai materi menggunakan pendekatan ilmiah, bahwa informasi bisa berasal dari mana saja, kapan saja, tidak bergantung pada informasi searah dari guru. Pembelajaran saintifik mengajarkan anak menemukan pengetahuan baru, memecahkan masalah, berpikir kritis dan menciptakan kreativitas sehingga membantu mereka memahami dunia, mengumpulkan dan mengolah informasi sebagai kunci dasar anak belajar berpikir luas. Oleh karena itu kondisi pembelajaran yang diharapkan diarahkan untuk 
mendorong peserta didik dalam mencari tahu dari berbagai sumber melalui observasi, dan bukan hanya diberi tahu (Suyadi, 2017 : 110).

Berdasarkan latar belakang ini, penulis tertarik untuk mengamati tentang pembelajaran Saintifik melalui metode bercerita untuk perkembangan kognitif anak di RA kelompok A Mambaul Ulum Sumurgung Montong Tuban. Adapun rumusan masalah dalam penelitian ini adalah: 1) bagaimana Implementasi pembelajaran saintifik melalui metode bercerita di RA kelompok A Mambaul Ulum 2) bagaimana metode/teknik bercerita untuk perkembangan kognitif anak di RA kelompok A Mambaul Ulum? 3) Apa faktor pendukung dan penghambat pelaksanaan pembelajaran Saintifik melalui Metode Bercerita untuk perkembangan kognitif anak?

\section{Implementasi Pembelajaran Saintifik melalui metode bercerita}

Implementasi dapat diartikan sebagai pelaksanaan atau penerapan dalam pembelajaran. Secara garis besar implementasi pembelajaran adalah suatu tindakan atau pelaksanaan dari sebuah rencana yang disusun secara matang dan terperinci dalam sebuah proses pembelajaran (Nurdin, 2011:34)

Pendekatan Saintifik adalah proses pembelajaran yang dirancang untuk membangun cara berfikir anak anak agar mereka memiliki kompetensi sikap,pengetahuan,dan keterampilan yang diperoleh melalui proses mengamati, menanya, mengumpulkan informasi, mengolah informasi/mengasosiasikan, dan mengkimunikasikan hasil berfikirnya (Hadiyan, 2017: 35). Pembelajaran saintifik dalam proses pembelajaran bermanfaat mengembangkan kemampuan berfikir anak. Pendekatan saintifik digunakan pada saat anak anak terlibat dalam kegiatan, baik itu dalam kegiatan sains ataupun kegiatan ketika guru sedang bercerita. Pembelajaran dengan pendekatan saintifik mengupayakan keterlibatan semua pancaindra yang ada, seperti dijelaskan berikut: 
1. Kegiatan mengamati yaitu dilakukan untuk mengetahui objek objek menggunakan indera, seperti melihat, mendengar, menghirup, merasa dan meraba.

2. Kegiatan menanya yaitu anak diajak untuk bertanya tentang objek yang diamati maupun hal lain yang ingin diketahui

3. Kegiatan mengumpulkan informasi dilakukan dengan melakukan, mencoba, mendiskusikan, dan menyimpulkan hasil dari berbagai sumber

4. Kegiatan mengolah informasi atau mengasosiasikan yaitu menghubungkan informasi yang sudah dimilki dengan informasi baru yang di dapatkan sehingga mendapatkan pemahaman yang lebih baik lagi tentang suatu hal

5. Kegiatan mengomunikasikan yaitu menyampaikan kembali hal hal yang telah dipelajari dalam berbagai bentuk misalnya melaui cerita, gerakan, hasil karya dan sebagainya.

Pelaksanaan pendekatan saintifik di sekolah telah menggunakan pedoman yang disesuaikan dengan karakteristik anak yang tercantum dalam kurikulum 2013 PAUD, beberapa prinsipnya adalah:

1. Mendukung anak dalam proses mencari tahun tentang sesuatu dengan caranya sendiri atau dengan bimbingan orang tua.

2. Mendukung anak untuk melakukan penemuanya sendiri

3. Menumbuhkan minat, mengembangkan gagasan dan kreativitas serta menguatkan perasaan anak terhadap sesuatu

4. Mendukung anak agar ia dapat mengomunikasikan hasil berpikirnya pada orang lain

Pembelajaran saintifik yang berlangsung tersebut seyogyanya dikemas dengan sesuatu yang menarik salah satunya melalui dengan bercerita. Bercerita merupakan metode yang tepat karena lewat cerita yang disampaikan, kita sedang menanamkan nilai nilai agama dan moral serta aspek sosial emosional 
yang berguna bagi pembentukan karakter anak (Hadiyan, 2018 : 2). Metode bercerita juga banyak terdapat di dalam Al-Qur'an yang tujuan pokoknya adalah untuk menunjukkan fakta dan kebenaran. Kebanyakan dalam setiap surat Al Qur'an terdapat cerita baik yang negatif maupun yang positif. Cerita tentang kejadian terutama sejarah, merupakan metode yang banyak ditemukan dalam Al Qur'an. Banyak bagian bagian Al Qur'an yang berisi kisah kiak kesejarahan atau peritiwa yang pernah terjadi atau setidaknya merupakan bagian yang dianggap cerita. Dalam surat Yusuf : 111

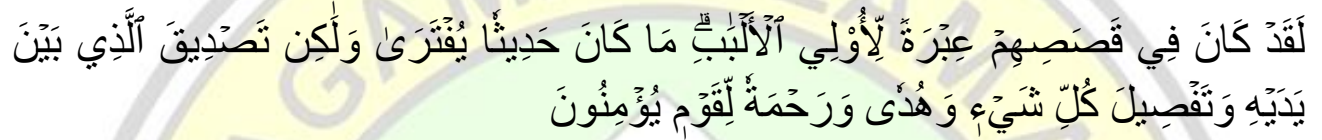

Artinya : Sesungguhnya pada kisah-kisah mereka itu terdapat pengajaran bagi orang-orang yang mempunyai akal. Al Quran itu bukanlah cerita yang dibuat-buat, akan tetapi membenarkan (kitab-kitab) yang sebelumnya dan menjelaskan segala sesuatu, dan sebagai petunjuk dan rahmat bagi kaum yang beriman.

Ayat tersebut mengandung makna bahwa cerita itu mengandung pelajaran yang bermakna bagi manusia, berdasarkan pemahamanya akan cerita yang terjadi di dalamnya. Ternyata bukan semata mata cerita kosong tetapi harus mendapatkan perhatian pemikiran atau kebahagiaan yang terletak dihati manusia berkenaan dengan cerita yang ada dalam Al Qur'an. Relevansi metode bercerita di lingkungan sekolah seolah olah seperti benar benar terjadi dengan sesungguhnya. Cerita cerita yang dimaksud merupakan metode yang samgat bermanfaat untuk menyampaikan informasi dan pelajaran. Disaat yang sama kita juga sedang mengasah kemampuan kognitif , bahasa, seni maupun fisik motorik anak. Hal ini penting bagi pembentukan generasi unggul di Indonesia, yaitu generasi yang sehat, kuat serta tangguh dalam menghadapi tantangandi era globalisasidan berbagai macam ancaman yang merusak. 
Bercerita memiliki manfaat yang besar dalam pembentukan jiwa manusia. Itu sebabnya keterampilan bercerita wajib untuk dipelajari dan dikuasai, terutama oleh para pendidik.dan orang tua. Salah satu penelitian David Mc Clellend, psikolog asal Amerika Serikat, menunjukkan bahwa bercerita memili pengaruh yang luar biasa bagi manusia . kegiatan bercerita bukan sekedar menitipkan pesan pesan moral kepada anak anak. Dari penelitian tersebut Mc Clellend berusaha mencari tahu pengaruh cerita dalam membangun kemajuan suatu bangsa.

Berdasarkan penelitian tersebut, diketahui bahwa cerita memiliki kekuatan yang besar untuk membentuk mental, karakter, dan sikap seseorang. Bukan hanya itu, bercerita memberikan manffat sebagai berikut :

1. Menguatkan jalinan ikatan anatara pendidik atau orang tua dengan anak

2. Melatih imajinasi dan kreatifitas sehingga anak menjadi lebih kritis serta cerdas

3. Meningkatkan kemampuan anak dalam hal berbahasa, mendengar dan berkomunikasi

4. Sebagai alat menyampaiakn pesan anak nilai nilai moral yang bermanfat untuk membangun karanter anak

5. Memperkenalkan berbagai bentuk emosi maupunn ekpresi kepada anak yang bermanfaat bagi pembentukan dan perkembangan kecerdasan emosinya

6. Sebagai media untuk pembentukan identifikasi diri anak

7. Memperkaya pengalaman batin anak

8. Memberikan dampak rasa atau bahagia karena cerita disampaikan sebagi hiburan 


\section{Metode/Teknik Bercerita Untuk Peningkatan Kognitif Anak}

Bercerita yang menarik tidak dimiliki bagi setiap orang, tetapi siapa saja bisa bercerita dengan baik jika mempunyai kemauan belajar yang tinggi. Berikut cara memulai bercerita menurut kak hadiyan (2018:14):

1. Belajar dari yang terbaik, mencari role model yaitu orang yang ahli dalam bidang yang kita geluti.

2. Larut sepenuhnya, jangan setengah setengah, melakukan dengan fokus, meluangkan banyak waktu untuk belajar dan larut sepenuhnya akan membuat semakin terampil

3. Pengulangan tanpa jeda, keahlian akan lebih terasa hika kita konsisten berlatih. Ketika kita tidak punya bakat, maka bekerja keras dan berlatih adalah jalanya.

Setelah kita sudah mengetahui hal hal yang diperlukan untuk memulai berceita , selanjutnya ada beberapa hal yang perlu disiapkan untuk menyampaikan cerita agar menarik :

1. Menentukan jenis cerita yang tepat

2. Mempersiapkan isi cerita agar meanarik bagi anak, isi cerita agar menarik juga dibutuhkan pendukung yang lain supaya isi tersebut semakin lengkap dan materi cerita dapat dipahami oleh anak anak, sebagai contohnya untuk mempersiapkan isi cerita yang menarik maka kita harus : olah suara, olah gerak, olah ekpresi wajah atau mimik

3. Membuat strategi aksi saat bercerita, ini teknik yang penting sebab dengan membuat strategi kita telah mempersiapkan semuanya dengan maksimal, dalam memilih cerita sebaiknya disesuaikan dengan karakteristik dan usia anak

4. Melakukan penilain usai bercerita, usai bercerita kita dapat melakukan penilain menggunakan saintifik yakni mengajak anak bertanya dan 
menjawab seputar isi cerita dan maknanya, dengan demikian kognitif anak juga akan terasah sesuai dengan pemahaman pemahaman dari isi cerita yang telah sampaikan ke anak

Kognitif adalah salah satu ranah dalam taksonomi pendidikan. Secara umum kognitif diartikan potensi intelektual yang terdiri dari tahapan pengetahuan (knowledge), pemahaman (comprehention), penerapan (aplication),analisa (analysis),sintesa (sinthesis), evaluasi (evaluation). Ranah kognitif adalah ranah yang mencakup kegiatan mental (otak).

Kata kognitif berasal dari bahasa latin cognitio, yang berarti 'pengetahuan'. Dalam ilmu psikologi perspektif kognisi adalah model psikologi yang berfokus pada pikiran,keyakinan,harapan,dan sikap serta bagaimana aspek aspek tersebut mempengaruhi perilaku manusia (Lusi, Indeks : 13-14). Para ahli psikologi kognisi meyakini bahwa interpretasi atau bagaimana kita memaknai peristiwa dalam dalam krhidupan kita. Jadi menurut mereka, yang menentukan kondisi emosi kita bukan semata mata peristiwa tesebut. Tokoh pendekatan kognisi ini antara lain albert, elis dan aaron beck.

Berdasarkan teori perkembangan diatas maka perkembangan kognisi menurut piaget anak anak yang berada pada kanak kanak lanjut pengembangan kognisinya berada pada tahap konkrit eperasional. Artinya anak anak mencapai struktur logika tertentu yang memungkinan mereka membentuk beberapa operasi mental, namun masih terdapat pada objec objec yang konkrit. Anak anak berpikir logis namun bukan sekedar berpikir abstrak.

\section{METODE}

Penelitian ini dilaksanakan di RA Kelompok A Mambaul Ulum Sumurgung Montong Tuban. Jenis penelitian yang digunakan adalah deskriptif kualitatif dengan pendekatan studi kasus. Menurut Moleong 
penelitian deskriptif kualitatif merupakan penelitian yang dimaksudkan untuk memahami fenomena tentang apa yang dialami oleh subjek penelitian, misalnya perilaku, persepsi, motivasi, tindakan, dan lain lain secara holistik dan dengan cara deskriptif dalam bentuk kata kata dan bahasa, alamiah dan dengan memanfaatkan berbagai metode alamiah (2007: 6). Sedangkan menurut Sugiyono metode penelitian kualitatif merupakan metode penelitian yang digunakan untuk meneliti pada kondisi obyek yang alamiah dimana peneliti sebagai instrumen kunci (2008: 9). Adapun objek dalam penelitian ini adalah kepala KB Mambaul Ulum, guru, dan orang tua siswa.

Teknik pengumpulan data dilakukan dengan teknik observasi, wawancara tidak terstruktur, dan dokumentasi. Sedangkan instrumen yang digunakan adalah lembar observasi. Data yang telah diperoleh kemudian dianalisis dengan reduksi data, penyajian data, dan kesimpulan.

\section{HASIL DAN PEMBAHASAN}

\section{Implementasi Pembelajaran Saintifik melalui metode bercerita}

Implementasi pembelajaran dengan pendekatan Saintifik adalah proses pembelajaran yang dirancang untuk membangun cara berfikir anak anak agar mereka memiliki kompetensi sikap, pengetahuan, dan keterampilan yang diperoleh melalui proses mengamati, menanya, mengumpulkan informasi, mengolah informasi/mengasosiasikan, dan mengkomunikasikan hasil berfikirnya. Melalui metode berceriita anak dapat memilki dan menumbuhkembangan pengetahuan mereka sesuai tema yang telah disampaikan oleh guru. Implementasi pembelajaran dengan pendekatan saintifik di RA kelompok A Mambaul Ulum dilaksanakan dengan menggunakan metode bercerita dimana guru menggunakan media buku dan media yang lain sesuai dengan tema cerita. Keberhasilan implementasi 
tersebut dapat dilihat keberhasilan pembelajaran dengan pendekatan saintifik yaitu:

a. Kegiatan mengamati, anak RA kelompok A Mambaul Ulum sudah mampu belajar dengan fokus dengan cerita yang disampaikan oleh guru dengan cara mengikuti pembelajaran dengan tenang dan fokus dan memahami sesui dengan perkembangan kognitif anak

b. Kegiantan bertanya, siswa RA Kelompok A Mambaul Ulum telah mampu bertanya ketika pembelajaran berlangsung, ini adalah respon yang positif karena bertanya merupakan awal dari pengetahuan dan perkembangan kognitif anak.

c. Kegiatan mengumpulkan informasi, siswa RA Kelompok A Mambaul Ulum sudah mampu mengumpulkan informasi dengan cara mengadakan percobaan dan melakukan pertanyaan

d. Kegiatan mengolah informasi, anak melakukan kegiatan dengan cara bertanya dan mengaitkan dengan apa yang telah diliat baik di kelas maupun diluar kelas tentang cerita yang telah disampaikan oleh guru

e. Kegiatan mengomunikasikan, kegiatan ini dilakukan oleh guru dengan menyampaikan kembali cerita dan mendapatkan respon yang positif dari siswa misalnya anak melakukan gerakan sebagai respon dari apa yang disampaikan guru.

\section{Metode/Teknik Bercerita Untuk Perkembangan Kognitif Anak}

Jean piaget menggambarkan masa kanak kanak sebagai tahap pre operasional (preoperational stage) yaitu tahap utama kedua dalam perkembangan kognitif piaget dimana seorang anak menjadi canggih dalam menggunakan pemikiran yang simbolis tetapi masih belum dapat menggunakan logika. Tahap pre operasional berlangsung pada usi 2-7 tahun, ditandai oleh ekspansi besar dalam pemikiran simbolis atau 
kemampuan refresentasi yang pertama kali yaitu muncul pada akhir tahap sensorimotorik (tahap pertama perkembangan kognitif).

Sedangkan menurut Vigotsky bahwa perkembangan kognitif anak usia dini lebih menekankan pengembangan konsep konsep yang lebih sistematis logis dan rasional . bagi anak usia dini pengetahuan tentang pengembangan konsep pembelajaran dan bermain itu sangat penting karena banyak menambah kreatifitas pada anak serta kesiapan mental mereka.

RA kelompok A Mambaul ulum melaksanakan pengembangan kognisi anak dengan menggunakan pendekatan saintifik dirancang dengan metode bercerita. metode bercerita menjadi salah satu jenis metode yang sangat tepat dilakukan di RA A mambaul ulum karena kebanyakan dari usia ini anak lebih menyuaki dunia cerita.

Cerita merupakan penuturan tentang suatu peristiwa atau kejadian yang disampaikan kepada orang lain, baik yang nyata maupun tidak nyata. Cerita nyata mengisahkan peristiwa yang benar benar terjadi, sedangkan cerita yang tidak nyata yaitu peristiwa yang tidak benar benar terjadi dan sengaja dibuat oleh pengarang berdasarkan khayalan dan imajinasinya.

Bercerita menjadi metode yang menarik dikalangan anak anak usia dini. Salah satunya di RA Kelompok A Mambaul Ulum Sumugung, metode bercerita menjadi salah satu metode yang menarik bagi guru karena dengan bercerita maka anak akan memperhatikan guru dan mendengarkan cerita yang disampaikan, untuk kemudian memahami materi yang disampaikan, karena usia anak RA merupakan usia dimana cerita dan dongeng menjadi nmenarik sesuai dengan umurnya dan perkembangan kognisinya. 
3. Apa Faktor pendukung dan penghambat pembelajaran Saintifik melalui Metode Bercerita untuk perkembangan kognitif anak RA kelopompok A Mambaul Ulum

Implementasi pendekatan saintifik melalui metode bercerita untuk pengembangan kognitif anak RA Keloppok A Mambaul Ulum dapat berhasil karena memiliki beberapa hal yang menajdi pendukung pelaksanaan, antara lain:

a. Program kepala RA terkait peningkatan kapasitas guru dalam bercerita yang rutin dilaksanakan oleh IGRA Kecamatan

b. Kapasitas guru terhadap setiap penguasaan materi cerita sesuai dengan tema.

c. Kemampuan guru dalam menggunakan teknik teknik dan metode yang menarik

d. Anak usia dini mempunyai kecenderungan lebih menyukai cerita dan dongeng

e. Kelengkapan media untuk bercerita sesuai tema

sedangkan penghambat dari pendekatan saintifik melalui metode bercerita RA A Mambaul Ulum, antara lain:

a. Kurang pendampingan orang tua siswa ketika berada dirumah untuk mempraktekkan/mengulang kembali materi/pengetahuan yang disampaikan guru.

b. RA Kelompok A Mambaul Ulum merupakan kelas besar menjadi salah satu faktor penghambat. 


\section{PENUTUP}

\section{Simpulan}

Pembelajaran dengan pendekatan saintifik mengajarkan anak menemukan pengetahuan baru, memecahkan masalah, berpikir kritis dan menciptakan kreativitas sehingga membantu mereka memahami dunia, mengumpulkan dan mengolah informasi sebagai kunci dasar anak belajar berpikir luas. Bercerita menggunakan pendekatan saintifik tidak harus menggunakan materi sains tetapi lebih kepada unsur unsur dalam penerapan sains yang meliputi proses mengamati, menanya, menyimpulkan informasi, mengolah informasi atau mengasosiasikan, dan mengomunikasikan setiap pesan dalam cerita. Metode bercerita menjadi sangat menarik bila dilakukan oleh guru yang memiki kepandaian dalam berimanjinasi tinggi. Guru wajib memiliki metode bercerita yang menarik agar siswa tingkat RA dapat menerima pesan maupun motivasi dalam cerita tersebut. Apabila dalam bercerita, guru telah mampu memusatkan perhatian anak kepadanya ketika pembelajaran sedang berlangsung, maka anak mempunyai respon yang positif, dan ketika respon positif tadi di dapatkan maka dapat dipastikan bahwa anak berfikir, dan melakukan proses berpikir inilah yang bisa menjadikan kognitif anak berkembang sesuai dengan tahapan perkembangan anak usia RA.

\section{DAFTAR PUSTAKA}

J Moleong, Lexy (2008). Metodologi penelitian kualitatif. Bandung : PT Rosdakarya

Johariyah, Siti dan Nadlifah. (2015). Scientific Learning Skill Of Islamic School Teachers And Students In Indonesia, IOSR Journal of Research \& Method in Education (IOSR-JRME), Volume 5, Issue 3 Ver. III (May - Jun. 2015) 
Moeslichatoen. (1998). Metode Pengajaran di Taman Kanak-Kanak. Jakarta : Rineka Cipta

Maryadi, Hadiyan (2018) Bercerita Tematik dengan pendekatan saintifik. Jakarta : Erlangga

Marwiyati, Siti (2017). Thesis : Pembelajaran Saintifik pada anak usia dini dalam pengemabngan kreativitas di TK Negeri Pembina kota Saltiga. Yogyakarya : Pascasarjana UIN Sunan Kalijaga Yogyakarta.

Nurdin dan usman. (2011). Implementasi pembelajaran. Yogyakarta : Rajawali Press

Nuryanti Lusi (2008). Pskilogi Anak. Jakarta : Indeks

R Semiawan, Conny (2008). Belajar dan pembelajaran pra sekolah dan sekolah dasar, Jakarta : Indeks

Suyadi dan Dahlia. (2014). Implementasi Dan Inovasi Kurikulum PAUD 2013 Program Pembelajaran Berbasis Multiple Intelligence. Bandung: Remaja Rosdakarya

Sugiyono. (2008). Metode penelitian kuantitatif, kualitatif dan $R \& D$. Bandung : ALFABETA

Suyadi dan Maulidya Ulfah (2013). Konsep Dasar PAUD. Bandung: Remaja Rosdakarya

Sumiyati. (2014). Konsep Dasar Pendidikan Anak Usia Dini dalam Islam. Yogyakarta: Cakrawala Institute. 